Acta vet. scand. 1988, 29, 231-238.

From the Department of Obstetrics and Gynaecology,

College of Veterinary Medicine, Hautjärvi, Finland.

\title{
Postpartum Reproductive Function in Finnish Ayrshire and Friesian Cows after Three Subsequent Parturitions
}

\author{
By K. Heinonen, E. Savolainen, V. Tuovinen, P. Miettinen and M. Alanko
}

\begin{abstract}
Heinonen, K., E. Savolainen, U. Tuovinen P. Miettinen, and M. Alanko: Postpartum reproductive function in Finnish Ayrshire and Friesian cows after three subsequent parturitions. Acta vet. scand. 1988, 29, 231-238. - The postpartum reproduction functions of 84 Finnish Ayrshire and Friesian cows were studied on an experimental farm. The cows were divided according to type of feed into 2 groups of equal size: a hay-urea group and a silage group. The duration of the study was 3 years. Eighty-four cows were followed during their first postpartum period, 63 during 2 and 57 during 3 consecutive post partum periods.

The cows were examined clinically by rectal palpation, and milk samples for progesterone assay were taken 3 times a week between calving and first insemination. External signs of heat were checked 3 times a day by the herdsmen.

Intervals from calving to completed uterine and cervical involution, appearance of first palpable follicle, onset of first luteal function and onset of regular ovarian function were recorded. Intervals from calving to the first observed heat and to pregnancy were measured and the rate of successful pregnancies at the first insemination was calculated.

Least squares methods were used for evaluation of the effect of individual cow, breed, parity/year and type of feed on postpartum reproductive function.

The cows in the herd seemed to have equal reproductive functions which were influenced by the conditions during each year/parity rather than by the breed or type of feed.

Individual cow effect was significant for the rapidity of uterine involution. Breed had no significant effect on any of the parameters studied.

The effect of type of feed alone was not significant for any parameter, but when studying the intervals from calving to uterine involution and initiation of luteal function differences between the feed groups were noted within parity/year.

The percentage of cows showing heat before the first dioestrus (luteal phase) increased with parity/year, and the first dioestrus was shorter than the second. The percentage of cows showing postoestrous bleeding increased with number of oestrous cycles post partum.
\end{abstract}

uterine involution; oestrus; postoestrous bleeding; feed.

\section{Introduction}

Factors such as management, breed, parity and nutrition influence the resumption of reproductive function after parturition.

The interval from calving to completed uterine involution is reported to vary between 22 and 49 days, and it increases with parity. Significant differences have been observed between breeds
(Marion et al. 1968, Morrow et al. 1969b, Moller 1970, Britt et al. 1974, Fonseca et al. 1983, Larsson et al. 1984).

The first follicles can be palpated 7-16 days post partum (Morrow et al. 1969a, Webb et al. 1980). The average interval from calving to first ovulation as determined by an elevation of progesterone values is reported to vary between $\mathbf{1 7}$ and $\mathbf{3 0}$ 
days in dairy cows (King et al. 1976, Webb et al. 1980, Fonseca et al. 1983, Larsson et al. 1984, Heinonen et al. 1987). Significant differences have been observed between breeds (Larsson et al. 1984). The first luteal phase is usually shorter than subsequent phases (Morrow et al. 1969a, Fonseca et al. 1983, Larsson et al. 1984).

Feed providing insufficient energy is related to delayed resumption of the oestrous cycle (Oxenreider \& Wagner 1971, Butler et al. 1981, Nakao et al. 1984). Regular ovarian function is reported to begin 40-50 days post partum without great differences between breeds or parities (Larsson et al. 1984, Heinonen et al. 1987).

The first visible oestrus occurs later than the first ovulation (Morrow et al. 1969a, Whitmore et al. 1974, King et al. 1976), without any significant effects of either breed or parity (Larsson et al. 1984). Deficient heat detection (King et al. 1976) and feed low in energy (Oxenreider et al. 1971, Heinonen et al. 1986) seem to be factors which may delay appearance of the first visible oestrus. The purpose of this study was to produce basic descriptive information concerning postpartum reproductive function in Finnish Ayrshire and Friesian cows during 3 subsequent postpartum periods, and also to study the effect of type of feed on reproductive function.

\section{Material and methods Animals}

Forty-two Finnish Ayrshire and 42 Finnish Friesian cows were included in the study. The animals, born to randomly selected heifers from different parts of Finland, were transported to the farm at the age of 1 to 2 months and were inseminated for the first time at the approximate age of 16 months. A total of 204 postpartum periods were examined during 3 years. Eighty-four cows were followed through their first postpartum period, 63 through 2 and 57 through 3 consecutive postpartum periods. The calving season was from April to August.

\section{Management of the herd}

The cows were housed indoors throughout the experiment and allowed outdoors in the paddock once a week.

At 4 months of age the cows were divided according to type of feed into a hay-urea group ( $\mathrm{HG})$ and a silage group (SG). All animals were fed according to Finnish feeding standards.

The forage given to the HG cows was based on dry hay ad libitum, and that of the SG cows on grass silage ad libitum. The SG animals were also given $1 \mathrm{~kg}$ dry hay daily. In addition, both groups were fed a concentrate containing $2 / 3$ barley and $1 / 3$ oats. Two per cent urea was added to the concentrate given to the $\mathrm{HG}$ animals as a source of nitrogen. On the day of calving, the $\mathrm{HG}$ cows were given $4.8 \mathrm{~kg}$ of concentrate and the SG cows 3.5 $\mathrm{kg}$. The amount of concentrate was increased at a rate of $0.3 \mathrm{~kg} /$ day for 10 days up to $7.8 \mathrm{~kg} /$ day (6.3 $\mathrm{kg}$ /day after the first parturition) for the HG cows and up to $6.5 \mathrm{~kg} /$ day $(5.0 \mathrm{~kg} /$ day after the first parturition) for the SG animals. Subsequently the concentrate ration was increased according to the daily milk yield up to $12.5 \mathrm{~kg}$ /day for the HG cows and $9.9 \mathrm{~kg} /$ day for the SG cows. These rations were used at a daily milk yield of $30 \mathrm{~kg}$ or more. Both groups were fed a mineral concentrate mixed in with the grain. The HG animals were also given a daily vitamin $\mathrm{ADE}$ concentrate.

The cows were milked twice a day with a $9 \mathrm{~h}$ interval between morning and afternoon milkings.

External signs of heat were recorded 3 times a day by the herdsmen. The cows were inseminated at the first detected heat after 60 days post partum by the local artificial insemination technician. The average milk yield of the herd was 4,162, 5,337 and 5,572 kg 4\% FCM during lactations 1, 2 and 3 respectively.

\section{Clinical examination and sampling}

All the animals were clinically examined at 2-3 day intervals between calving and first insemination. The examination included inspection of 
the vulva and rectal palpation of the cervix, uterus and ovaries.

Milk samples for progesterone assay were taken immediately after morning milking every Monday, Wednesday and Friday from calving to the first insemination. Milk was collected in plastic tubes containing $100 \mathrm{mg}$ sodium azide as a preservative. Samples were analysed within 3-4 days by a commercial RIA method (Whole milk progesterone assay, Farmos Diagnostica, Finland, Laitinen 1983).

\section{Recording of clinical findings}

Uterine involution was considered complete when the uterus felt symmetrical and its position was within, or at the edge, of the pelvic cavity (uterine involution 1). After the second and third parturitions the time needed for the uterine horn diameters to reach their minimum difference was also registered (uterine involution 2). The time from calving until the middle of the cervix reached the minimum diameter was registered as the end of cervical involution. The interval from parturition to the appearance of the first follicle $\geq 1 \mathrm{~cm}$ in diameter was registered. The clinician performing the rectal examinations was not informed of the previous findings. The data were collected by 4 separate investigators; 1 each for the first and third parturitions and 2 for the second.

In the present material the milk progesterone level reached $8 \mathrm{nmol} / 1$ 3-5 days after oestrus. Thus progesterone values of $\geq 8 \mathrm{nmol} / \mathrm{l}$ were considered as indicative of luteal function. The onset of the first luteal function (first dioestrus) was recorded when the milk progesterone value or values reached $8 \mathrm{nmol} / \mathrm{l}$. Initiation of regular cycling was recorded after 5 or more consecutive progesterone values of $\geq 8 \mathrm{nmol} / 1$, indicating a dioestrous period of more than 14 days. Visible heat was determined as observed oestrus followed by an increase in milk progesterone concentration. Pregnancies were confirmed by rectal examination at 6-8 weeks post insemination. Animals which aborted later than 6-8 weeks post insemination were regarded as pregnant. Animals that were not pregnant before 150 days post partum were regarded as infertile. The overall pregnancy rate, the pregnancy rate at the first insemination and the interval from calving to pregnancy were calculated for each cow. Only animals with spontaneous resumption of cyclic ovarian function were included; animals treated for ovarian cysts were excluded.

\section{Statistical analysis}

The effects of breed, parity and feeding group on reproductive traits were studied by the GLM procedure in the Statistical Analysis System ( $S A S$ Institute Inc. 1985). In the preliminary analysis the model consisted of the effects of breed, type of feed, parity, individual cow, interaction between parity and type of feed, and interaction between parity and breed. Since breed, type of feed and interaction between parity and breed were not found to be significant, they were omitted from the final model, giving:

$\mathrm{Y}_{\mathrm{ijk} \mathrm{l}}=\mu+\mathrm{P}_{\mathrm{i}}+(\mathrm{pxf})_{\mathrm{ij}}+\mathrm{c}_{\mathrm{k}}+\mathrm{e}_{\mathrm{ijk}}$

where

$\mathrm{Y}_{\mathrm{ijkl}}=$ the $\mathrm{i}, \mathrm{j}, \mathrm{k}, \mathrm{l}$ th observation

$\mu \quad=$ the overall mean

$\mathbf{P}_{\mathrm{i}} \quad=$ the effect of ith parity

$(p x)_{i j}=$ interaction effect between ith parity and jth group of feeding

$c_{k}=$ random effect of the individual cow

$\mathrm{e}_{\mathrm{ijk}}=$ residual random term

All the effects, except for the individual cow effect, were regarded as fixed. To satisfy the distributional condition of normality, logarithms of intervals from calving to completion of uterine involution, initiation of luteal function, insemination and pregnancy were used.

The chi-square test was used when comparing categorical data between separate groups. 
Table 1. Intervals between calving and consecutive reproductive events in dairy cows after 3 consecutive calvings. Uterine involution defined in terms of uterine position within the pelvic cavity.

\begin{tabular}{lccccc}
\hline Interval (days) & & & \multicolumn{3}{c}{ Percentile } \\
\cline { 3 - 5 } from calving to: & $\mathrm{n}$ & Mean+s.e.m. & 50 & 75 & 90 \\
\hline Uterine involution & 201 & $20.4 \pm 0.4$ & 19 & 21 & 26 \\
Cervical involution & 201 & $29.8 \pm 0.5$ & 29 & 33 & 37 \\
Initiation of luteal function & 204 & $31.3 \pm 1.0$ & 29 & 36 & 48 \\
Initiation of regular cycling & 190 & $41.3 \pm 1.2$ & 40 & 52 & 64 \\
1st visible oestrus & 189 & $44.4 \pm 1.2$ & 43 & 54 & 65 \\
Pregnancy & 174 & $81.4 \pm 1.6$ & 77 & 90 & 107 \\
\hline
\end{tabular}

$\mathrm{n}=$ number of postpartum periods

\section{Results}

No breed-related differences were observed in the reproductive parameters studied. Intervals between calving and consecutive reproductive events after 3 calvings are summarized in Table 1 .

\section{Uterine and cervical involution}

The time needed for uterine involution decreased with increasing parity/year. The intervals from calving to completed uterine and cervical involution are shown in Table 2. After the first calving, the type of feed seemed to affect uterine involution, which was completed at 20.6 \pm 0.7 days in HG cows and $25.4 \pm 1.0$ days in $S G$ cows $(p<0.01)$. Similar differences were not noted after the second or third parturition. Involution of the cervix took 5 days longer after the second parturition than either the first or third.

\section{Resumption of ovarian activity}

The first follicles $\geq 1 \mathrm{~cm}$ in diameter were noted $16.3 \pm 1.1$ days post partum.

The intervals from calving to the first luteal function are shown in Table 2, and to initiation of the regular ovarian cycle in Table 5. Following the second parturition, the first elevation in milk progesterone occurred $34.1 \pm 2.4$ days post partum in the $H G$ animals and $26.5 \pm 1.9$ days post partum in the SG animals $(p<0.01)$. The regular oestrus cycle began later in the HG cows $(46.1 \pm 3.2$ days

Table 2. Intervals between calving and completed uterine ( $U$ inv. 1 and $U$ inv. 2 ) and cervical ( $C$ inv.) involution and 1 st diestrus in relation to individual cow and the interaction between type of feed and parity/year in dairy cows of equal parity after 3 consecutive calvings. $U$ inv. 1 defined as uterine position within the pelvic cavity, $U$ inv. 2 defined as uterine horn diameters in minimum. First dioestrus defined as 1st milk progesterone value of $\geq 8 \mathrm{nmol} / 1$.

\begin{tabular}{|c|c|c|c|c|c|}
\hline \multirow[b]{2}{*}{ Parity } & \multirow[b]{2}{*}{$\mathrm{n}$} & \multirow[b]{2}{*}{ U inv. 1} & \multicolumn{3}{|c|}{ Mean interval (days) \pm SEM from calving to: } \\
\hline & & & U inv. 2 & C inv. & 1st diestrus \\
\hline 1 & 84 & $23.0 \pm 0.6^{\mathrm{a}}$ & - & $28.2 \pm 0.7^{a}$ & $32.8 \pm 1.4^{\mathrm{a}}$ \\
\hline 2 & 63 & $20.2 \pm 0.8^{b}$ & $30.3 \pm 1.3^{\mathrm{a}}$ & $33.3 \pm 0.9 b$ & $30.2 \pm 1.6^{\mathrm{a}}$ \\
\hline 3 & 57 & $16.6 \pm 0.4^{c}$ & $26.9 \pm 0.6^{a}$ & $28.4 \pm 0.8^{\mathrm{a}}$ & $28.2 \pm 1.3^{a}$ \\
\hline $\begin{array}{l}\text { Level } \\
\text { cow } \\
\text { feedin }\end{array}$ & $\begin{array}{l}\text { significance } \\
\text { parity/year }\end{array}$ & $\begin{array}{l}* \\
* * \\
\end{array}$ & $\begin{array}{c}- \\
\text { N.S. }\end{array}$ & $\begin{array}{l}\text { N.S. } \\
\text { N.S. }\end{array}$ & $\begin{array}{c}\text { N.S. } \\
* *\end{array}$ \\
\hline
\end{tabular}

a,b,c: groups with different superscripts within the same column differ significantly in terms of the variable listed $(\mathrm{p}<0.01)$.

${ }^{*} \mathrm{p}<0.05, \quad{ }^{* *} \mathrm{p}<0.01, \quad$ N.S. not significant.

$\mathrm{n}=$ number of cows. 
Table 3. Length of 1 st and 2 nd oestrous cycles after parturition. 204 postpartum periods after 3 consecutive calvings in dairy cows.

\begin{tabular}{|c|c|c|c|}
\hline \multirow{2}{*}{$\begin{array}{l}\text { Length of } \\
\text { cycle (days) }\end{array}$} & \multicolumn{2}{|c|}{ Percentage of cows } & \\
\hline & 1st cycle & 2nd cycle & \\
\hline$<18$ & 74.7 & 8.5 & $\mathrm{p}<0.001$ \\
\hline $18-24$ & 23.9 & 89.1 & $\mathrm{p}<0.01$ \\
\hline$>24$ & 1.4 & 2.4 & N.S. \\
\hline
\end{tabular}

Significance calculated with the chi-square test.

post partum) than in the SG cows (35.8 \pm 2.0 days post partum) $(\mathrm{p}<0.01)$. No similar differences were observed either after the first or third parturition.

The first oestrous cycle to follow parturition was shorter than the second. Cycles longer than 24 days were observed only occasionally (Table 3 ). The percentage of cows showing heat before the first and second dioestrus was lowest after the first parturition (Table 4). The percentage of cows showing postoestrous bleeding increased with number of oestrous cycles after calving (Table 4). Postoestrous bleeding only occurred following oestrus with a subsequent increase in milk progesterone.
Table 4. External signs of heat and postoestrous bleeding during the follicular phases preceding the 1st and 2nd dioestrus after 3 consecutive calvings in dairy cows.

\begin{tabular}{|c|c|c|c|c|c|}
\hline \multirow[b]{3}{*}{ Parity } & \multirow[b]{3}{*}{$\mathbf{n}$} & \multicolumn{4}{|c|}{ Percentage of cows showing } \\
\hline & & \multicolumn{2}{|c|}{ external signs of heat } & \multicolumn{2}{|c|}{ postoestrous bleeding } \\
\hline & & 1st cycle & 2nd cycle & 1st cycle & 2nd cycle \\
\hline 1 & 84 & $9.2^{\mathrm{a}}$ & $* * * 67.1^{\mathrm{a}}$ & $39.7^{\mathrm{a}}$ & $* 62.7^{\mathrm{a}}$ \\
\hline 2 & 63 & $13.6^{\mathrm{b}}$ & $* * * 86.4^{b}$ & $22.3^{b}$ & $* 40.0^{b}$ \\
\hline 3 & 57 & $25.0^{c}$ & $* * * 89.9^{b}$ & $23.8^{\mathrm{b}}$ & ** $52.8^{\mathrm{a}, \mathrm{b}}$ \\
\hline Total & 204 & 15.2 & $* * * 78.0$ & 27.9 & $* * * \quad 50.5$ \\
\hline
\end{tabular}

Significance calculated with the chi-square test. a,b,c: groups with different superscripts within the same column differ significantly in terms of the variable listed $(\mathrm{p}<0.05)$.

Within number of cycle: * $\mathrm{p}<0.05, \quad{ }^{* *} \mathrm{p}<0.01$, $* * * \mathrm{p}<0.001$.

$\mathrm{n}=$ number of cows.

\section{Fertility}

The fertility parameters are presented in Table 5 . The first insemination was performed $71.5 \pm 0.8$ days post partum irrespective of feed group or parity. Following the second parturition, the SG animals had a lower pregnancy rate at the first insemination (42.4\%) than the HG animals $(60.6 \%)$, but the difference was not statistically

Table 5. Intervals between calving and initiation of regular ovarian activity (reg. act.), 1st oestrus and pregnancy, and pregnancy rate at 1st insemination (AI) in relation to individual cow and the interaction between type of feed and parity/year in dairy cows of equal parity after three consecutive calvings. 1st oestrus defined as oestrus followed by elevation in milk progesterone. Regular ovarian activity defined as 1st oestrus cycle of $\geq 18$ days.

\begin{tabular}{lccccc}
\hline & & \multicolumn{3}{c}{ Interval (days) \pm SEM from calving to: } \\
\cline { 2 - 6 } Parity & $\mathrm{n}$ & reg.act. & 1st oestrus & pregnancy & pregn. \% \\
\hline 1 & 84 & $41.9 \pm 1.7^{\mathrm{a}}$ & $50.3 \pm 1.7^{\mathrm{a}}$ & $81.2 \pm 2.4^{\mathrm{a}}$ & $67.1^{\mathrm{a}}$ \\
2 & 63 & $40.9 \pm 2.1^{\mathrm{a}}$ & $42.3 \pm 2.0^{\mathrm{b}}$ & $84.5 \pm 2.8^{\mathrm{a}}$ & $51.4^{\mathrm{b}}$ \\
3 & 57 & $40.9 \pm 2.1^{\mathrm{a}}$ & $39.3 \pm 1.9^{\mathrm{b}}$ & $77.5 \pm 2.2^{\mathrm{a}}$ & $78.6^{\mathrm{a}}$ \\
Level of significance for: & & & & \\
cow & N.S., & N.S. & N.S. & N.S. \\
feeding $\times$ parity & $* *$ & N.S. & N.S. & N.S. \\
\hline
\end{tabular}

a,b: groups with different superscripts within column differ significantly in terms of the variable listed $(p<0.05)$.

${ }^{*} p<0.05$, N.S. not significant.

$\mathrm{n}=$ number of cows. 
significant $(\mathrm{p}>0.05)$. The overall pregnancy rate was slightly lower after the first and second calving than after the third: $7 / 84,6 / 63$ and $2 / 57$ cows were excluded for infertility after the first, second and third parturition, respectively.

The incidence of retained placenta was 7/84 after the first parturition and $4 / 63$ after the second $(p>0.1)$. Values for the third parturition were not avaible. The incidence of treated ovarian cysts was $1 / 84,3 / 63$ and $3 / 57$ after the first, second and third parturition, respectively.

\section{Discussion}

The purpose of the present study was to describe reproductive events during 3 consecutive postpartum periods in 2 Finnish dairy breeds given 2 different types of feed. The methods used in measuring the events are available in ordinary field practice.

The course of the puerperium was similar to that described in earlier reports, with the exception of rate of uterine involution. The average time from calving to completed uterine involution was shorter in this study than in earlier reports by Marion et al. (1968), Fonseca et al. (1983), and Larsson et al. (1984). In addition, the interval seemed to decrease with increasing parity/year, which is contrary to earlier reports (Larsson et al. 1984). This discrepancy may be the result of a different definition of involution in the present study, according to which the criteria for completed uterine involution were localisation of the uterus in the pelvic cavity and symmetric uterine horns. The uterine horn diameters were measured only after the second and third parturitions. If the criterion had been the end of reduction in uterine horn diameter, this would have prolonged involution times by roughly 10 days, corresponding more closely to previous reports. Even with the later criteria, however, the involution time was still longer, although not significantly, after the second parturition than after the third. One possible explanation is that the animals in the present study were all of the same age and the effects of parity, year and clinician could not be separated.
The type of feed only affected the reproductive function insofar as parity/year was concerned. This might indicate that differences in reproductive function are not so much related to the type of feed as they are to the conditions prevalent during the year. Breed had no effect on the parameters studied; both Ayrshires and Friesians had very similar reproductive functions under comparable managerial conditions.

The first visible oestrus occurred roughly 2 weeks earlier in this study than in another Finnish study carried out under ordinary field conditions (Heinonen et al. 1987). Nevertheless the intervals from calving to the initiation of ovarian function were the same in both trials. This probably results from more accurate oestrus detection on the experimental farm than on average dairy farms. In agreement with a previous study (Larsson et al. 1984), the percentage of cows with external signs of heat increased with cycle number, but in our study it also increased with parity/year.

After the second parturition, the pregnancy rate at first insemination was low and luteal function and regular cycles began earlier in the SG than in the HG animals, but the latter seemed to have a higher pregnancy rate on first insemination. No reason for the low pregnancy rate could be found.

In conclusion, the results of this study indicate that both breeds have equal reproductive capacity irrespective of type of feed. All measurements were among animals treated identically, and possible differences between breeds and feeding groups could therefore be investigated. Because these cows were all of the same age it was not posible to differentiate between the effects of parity and annual conditions. Further research is needed to discover the reasons for differences in reproductive function between parities/years. These experimental cows were kept in a strictly managed environment in which they were not pasture-fed, and it is therefore questionable whether these results are representative of all Finnish herds. Further research is also needed to determine whether or not the inclusion of longer periods of outdoor grazing affects reproductive function. 
It should be remembered that in the present study pregnancies were confirmed 6-8 weeks after insemination, and that later abortions could therefore affect the final calving interval.

\section{Acknowledgements}

The authors wish to thank Dr. Asko Mäki-Tanila for help with the statistical analyses, and the personnel of the North-Savo Research Station for assistance in collecting the data.

This study was supported by grants from the Finnish Academy of Sciences (29/097), Valio and Hoechst Fennica Ab.

\section{References}

Britt JH, Morrow DA, Kittok RJ \& Seguin BE: Uterine involution, ovarian activity and fertility after melengestrol acetate and estradiol in early postpartum cows. J. Dairy Sci. 1974, 57, 89-92.

Butler WR, Everett RW, Coppock CE: The relationship between energy balance, milk production and ovulation in postpartum Holstein cows. J. Animal Sci. $1981,53,742-748$.

Fonseca FA, Britt JH, McDaniel BT, Wilk JC, Rakes $A H$ : Reproductive traits of Holsteins and Jerseys. Effects of age, milk yield and clinical abnormalities on involution of cervix and uterus, ovulatation, estrous cycles, detection of estrus, conception rate and days open. J. Dairy Sct. 1983, 66, 1128-1147.

Heinonen $K$, Alanko M, Ettala $E$ : Effects of feeding during the post-partum period on the genital function of dairy cows. Proceedings, XV Nordiska Veterinärkongressen, Stockholm 1986, p. 237-240.

Heinonen K, Gröhn Y, Linberg L-A, Alanko M: The effect of mild fat infiltration in the liver on the fertility of Finnish Ayrshire cows. Acta vet. scand. 1987, $28,151-155$.

King GJ, Hurnik JF, Robertson HA: Ovarian function and estrus in dairy cows during early lactation. $J$. Anim. Sci. 1976, 42, 688-692.

Laitinen J: Oestrus confirmation, pregnancy diagnosis and post-partum follow up of the Finnish dairy cows by milk progesterone assay: Effect of breed, season, feed and sampling on milk progesterone levels. Thesis. Publications of the University of Kuopio Natural Sciences Original Reports 1983, 1, 39-40.

Larsson K, Jansson L, Berglund B, Edqvist L-E, Kindahl $\mathrm{H}$ : Postpartum reproductive performance in dairy cows I: Influence of animal, breed and parity. Acta vet. scand. 1984, 25, 445-461.

Marion GB, Norwood JS, Gier HT: Uterus of the cow after parturition: factors affecting regression. Amer. J. Vet. Res. 1968, 29, 71-75.

Moller $K$ : Uterine involution and ovarian activity after calving. N.Z. Vet. J. 1970, 18, 140-145.

Morrow DA, Roberts SJ, McEntee K: Postpartum ovarian activity and involution of the uterus and cervix in dairy cattle. 1. Ovarian activity. Cornell Vet. 1969a, 59, 173-189.

Morrow DA, Roberts SJ, McEntree K: Postpartum ovarian activity and involution of the uterus and cervix in dairy cattle. 2. Involution of uterus and cervix. Cornell Vet. 1969b, 59, 190-210.

Nakao T, Yoshimeki S, Moriyoshi M, Kawata K: Effect of energy and protein intake on ovarian activity in postpartum high-producing holstein cows. Proc. 13th Congr. on Diseases of Cattle, Durban 1984, 2 , 803-808.

Oxenreider $S L$, Wagner WC: Effect of lactation and energy intake on postpartum ovarian activity in the cow. J. Anim. Sci. 1971, 33, 1026-1031.

SAS Institute Inc.: SAS User's Guide. SAS Institute Inc., Cary, N.C. 1985.

Webb $R$, Lamming $G E$, Haynes NB, Foxcroft $G R$ : Plasma progesterone and gonadotrophin concentrations and ovarian activity in post-partum dairy cows. J. Reprod. Fert. 1980, 59, 133-143.

Whitmore HL, Tyler WJ, Casida LE: Effects of early postpartum breeding in dairy cattle. J. Anim. Sci. 1974, 38, 339-346.

\section{Sammenfatning}

Den postpartuma reproduktiva funktionen hos finska Ayrshire och Frisiska kor, efter tre pà varandra följande kalvningar.

84 finska Ayrshire och frisiska kors postpartuma reproduktiva funktion undersöktes på en försöksgård. Korna indelades på basen av utfodring i 2 lika stora grupper: En hö-ureagrupp och en ensilagegrupp. Undersökningen varade $\mathrm{i}$ tre år. 84 kor undersöktes under deres första postpartuma period, 63 kor under 2 och 57 kor under 3 på varandra följande postpartuma periorder.

Korna undersöktes kliniskt med rektal palpation, och mjölkprov för progesteronmätning togs 3 gånger per vecka under tiden mellan kalvning och den första insemi- 
nationen. Yttre tecken på estrus kontrollerades 3 gånger per dag av djurskötarna.

Tiden mellan kalvning och fullständig uterin och cervical involution, uppkomsten av den första palperbara follikeln, den första luteala funktionens start samt den regelbundna ovariefunktionens start registrerades. Tiden mellan kalvning och första observerade estrus och dräktighet mättes och andelen lyckade dräktligheter vid första insemination uträknades.

Minsta kvadratmetoden användes då betydelsen av ko individ, ras, kalvningar/är och fodertyp på den postpartuma reproduktiva funktionen evaluerades.

Korna i gruppen verkade att ha likadana reproduktiva funktioner som påvrerkades mer av förhảllandena under året/dräktigheten än av ras- eller foderskillnader.
Individeffekten var signifikant då det gällde hastigheten av uterin involution. Rasen hade ingen signifikant betydelse för någon av de parametrar som undersöktes. Typen av foder hade ensam ingen signifikant betydelse för någon undersökt parameter men då tiden mellan kalvning och uterin involution samt start av luteal funktion undersöktes upptäcktes skillnader gällande kalvningar/år mellan fodergrupperna.

Andelen kor med ytre tecken på estrus före första dioestrum (luteal fas) ökade med antalet kalvningar/år, det första dioestrum var kortare än det andra. Antalet kor med postestrumala blödningar ökade med antalet estrumperioder efter kalvning.

(Received December 10, 1987).

Reprints may be requested from: Kalevi Heinonen, Department of Obstetrics and Gynaecology, College of Veterinary Medicine, SF-04840 Hautjärvi, Finland. 